\title{
Using Power of Calculated Electrons to Cut, Analyze and Exterminate the Outer and the Inner Biological Elements of Hepatitis C Virus without Blood Parameters Disorders: In Vitro Study
}

\author{
Waleed Ezzat Madboly ${ }^{1 *}$, Magdi Gebril Shehata ${ }^{2}$, Michael Sobhy M. Nashed ${ }^{3}$ \& Ahmed M. Abu-Dief ${ }^{4,5}$ \\ ${ }^{1}$ National Research Center, Center of Scientific Excellence for Influenza Viruses, 12622, Dokki, Giza, Egypt. \\ ${ }^{2}$ Department of Entomology, Faculty of Science, Ain Shams University, Cairo 11566, Egypt. \\ ${ }^{3}$ Medical Science Department, Faculty of Dentistry, Misr International University, El-Kilo 28, 11828, Cairo, Egypt. \\ ${ }^{4}$ Department of Chemistry, College of Science, Taibah University, Madinah, P.O. Box 344, Saudi Arabia. \\ ${ }^{5}$ Department of Chemistry, Faculty of Science, Sohag University, Sohag-82534, Egypt. \\ Corresponding Author Email: lrd10.info@gmail.com ${ }^{I^{*}}$
}

DOI: http://doi.org/10.38177/ajast.2022.6108

Copyright: () 2022 Waleed Ezzat Madboly et al. This is an open access article distributed under the terms of the Creative Commons Attribution License, which permits unrestricted use, distribution, and reproduction in any medium, provided the original author and source are credited.

\section{ABSTRACT}

Recently, the prevention and treatment of hepatitis $\mathrm{C}$ virus $(\mathrm{HCV})$ complications consider as major obstacles to reducing HCV outbreaks worldwide Therefore, it is crucial to develop a new alternative therapy for HCV infection with low cost and low side effects. A smart device termed a Life Restoration Device (LRD) was designated to produce a low potential codified amount of ions. The specified codified amount of ions produced from LRD are designated to exterminate HCV. To investigate our hypothesis, we designated an experimental system for in-vitro studies. This system is composed of a glass tube that can be filled with HCV polymerase chain reaction (PCR)-positive serum. The result of this study showed that LRD can decrease the viral load of HCV PCR-positive serum to $99 \%$ after 2 hrs treatment. The viral load reduction of the LRD against low HCV PCR count was almost similar to that of high HCV PCR count. Furthermore, the efficacy of LRD to reduce the serum viral load after 30 min or 60 min treatment was $74 \%$ or $95 \%$ respectively while the viral load after 2 hrs treatment was about $91 \%$. The electron microscopy investigation of HCV PCR-positive serum after treatment with LRD showed degenerated HCV particles compared with the non-treated virus. The in vitro treatment of the HCV PCR-positive serum with LRD didn't affect the blood contents such as red blood cells count, white blood cells count and hemoglobin levels. The sincerity of the codified amount of ions produced by LRD may affect the fragile fluidity of the viral envelope. Treatment of hepatitis viruses with a codified amount of ions is a new alternative therapy but needs more studies. It is crucial to develop an effective alternative viral therapy using such kind of technology to reduce the antiviral drugs side effects.

Keywords: Life restoration device, Codified amount of ions, Viral load, Hepatitis C virus, Low side effects.

\section{Introduction}

Chronic viral hepatitis is considered a major public health problem throughout the world that produces disorders for hundreds of millions of people [1]. Previously it is well known that viral hepatitis is the main cause of high ratios of morbidity and mortality in the human population [2]. There are five types of hepatitis viruses termed as hepatitis A, hepatitis B, hepatitis C, hepatitis D and hepatitis E [3]. All types of hepatitis caused disorders for humansranging from mild to severe chronic active/inactive hepatitis and cirrhosis [4]. One example of hepatitis disorders is hepatocellular carcinoma. Recently, hepatocellular carcinoma considered one of the ten most common cancers worldwide. The hepatocellular carcinoma is mainly associated with hepatitis B, or in some cases with hepatitis C virus (HCV) $[5,6]$.

Recently HCV is one of the serious hepatitis viruses which causes severe disorders in the liver and sometimes due to death. HCV has emerged as the main trigger of lymphoproliferative disorders, due to lymphotropism, and extra-hepatic manifestations which affecting other organ systems [7]. Notably, different treatment strategies against HCV infectivity reduction were developed. Antiviral drugs are the main strategy for HCV eradication. The main aim of antiviral strategy 
Asian Journal of Applied Science and Technology (AJAST)

Volume 6, Issue 1, Pages 61-76, January-March 2022

treatment is to eradicate HCV. Mainly antiviral treatment was based on the combination of pegylated interferon and ribavirin [8]. However, the effectiveness of the antiviral treatment strategy, produces severe side effects. These side effects include organic side effects, such as hematologic disorders, and functional side effects, such as headache, fever, fatigue $[9,10]$. Another strategy to prevent HCV infection is vaccinations. The HCV vaccine can prevent transmission, regardless of risk factors, and can significantly decrease the global burden of HCV-associated side effects. However, there are many barriers to the development of an HCV effective vaccine such as limited models for testing vaccines, and our incomplete understanding of protective immune responses against $\mathrm{HCV}$ vaccine $[11,12]$.

Recent studies focused on the alternative therapies of HCV. The alternative therapy of HCV treatment is effective, low cost as well as produces lower side effects [13,14]. Of note, HCV diseases and anti-HCV drugs side effects can be effectively treated by natural products. For example, the silymarin supplement extracted from the milk thistle is most widely used for liver diseases treatment includes HCV infection disorders $[13,14]$.

Another alternative therapy of pathogen is using ultraviolet light or electric frequencies $[15,16]$. In this treatment, the inactivation of many non-enveloped and enveloped pathogens using a higher intensity of broad- spectrum pulsed light was recently considered as pathogens alternative therapy. Furthermore, ultraviolet light considers an effective method to reduce viral infection. Interestingly, a comparison of ultraviolet irradiation of two-wavelength ranges (280-320 nm and lower than $280 \mathrm{~nm}$ ) showed that lower wavelength particularly inactivates non-enveloped viruses $[15,16]$. Notably, this type of non-invasive or alternative therapy of viral infection is relatively preferable because it is characterized by low cost, safe, low side effects and higher effectiveness.

Here, in this study, we designated a codified amount of ions producing device, termed as Life Restoration Device (LRD). This device was registered in the Patent office, Ministry of Higher Education, Academy of Scientific Research and Technology, Cairo, Egypt and has a patent number: 2014101664/2014/10/20. The function of LRD is to exterminate hepatitis viruses using a low potential codified amount of ions. The scientific base of LRD work is the electronic transformation of low voltage electric impulses into codified energy with specific and tiny stimulation ability. The produced codified energy is coded to destroy the biological contents of hepatitis virus such as a viral envelope or RNA/DNA.

In vitro treatment of HCV polymerase chain reaction (PCR)-positive serum with LRD significantly reduced the viral load in a short time. The efficacy of the LRD towards HCV extermination of high virus concentration and with low concentration was almost the same. The collected data in this study will be helpful to develop an alternative hepatitis virus therapy with low cost, short time and higher efficacy. The short time of viral load reduction of hepatitis viruses using LRD might reduce symptoms and side effects of hepatitis viruses when antiviral drugs are used. 


\section{Methods}

\subsection{LRD scientific theory for in vitro study}

The design of LRD is based on the cumulative application of a simple safe range of energy according to a proprietary formula to produce a specified codified amount of ions. The codified amount of ions produced from the LRD system will be transmitted through HCV PCR-positive serum and affects the fragile envelope and biological contents of the virus. As shown in Fig. 1 the LRD is mainly composed of two parts, a designated a glass tube as a container for HCV PCR-positive virus and the main part of LRD for the codified amount of ions production. There are two nickel-coated copper rods connected with a glass tube from both sides and the LRD for the codified amount of ions transmission through the serum. To evaluate the efficacy of the LRD against $\mathrm{HCV}$, the codified amount of ions produced from the LRD was applied on the HCV PCR-positive serum at different time points. The viral load of HCV in the serum before and after treatment was analyzed using PCR. All experiments are performed under the ethical guidelines for the use of human samples and approved by the ethical guidelines committee in Cairo University, Cairo, Egypt.

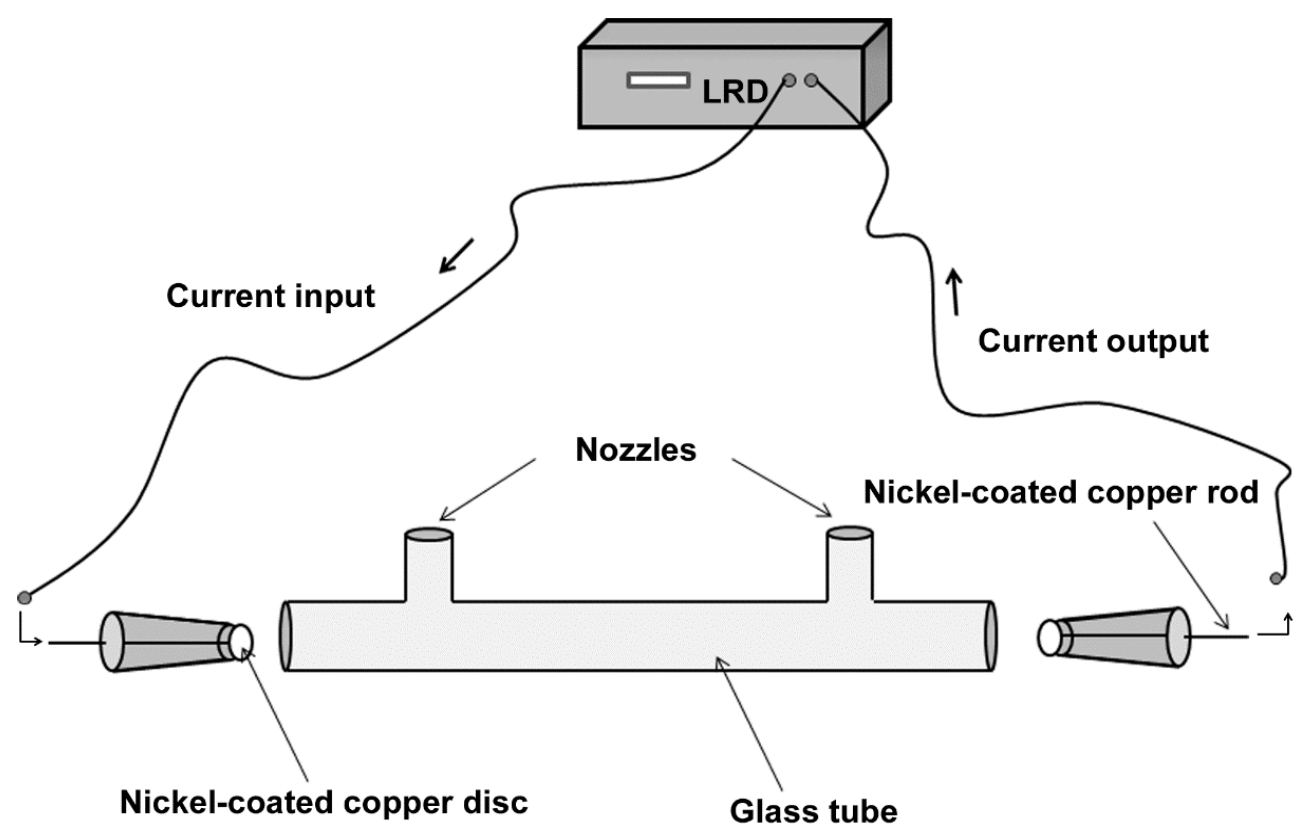

Fig.1. Diagrammatic graph showing the in vitro viral treatment system design. The glass tube will be filled with HCV PCR-positive serum. Then the two ends of nickel-coated copper rods will be connected with the LRD through specified wire. The codified amount of ions will be produced and controlled through the LRD

\subsection{Experimental system design}

As shown in Fig.2, two ml of HCV PCR-positive serum (2ml) were poured into the designated glass tube. Both input and output plugs were used to support nickel-coated copper rods and plug glass tube ends to prevent serum leakage. Hereafter, each side of the nickel-coated copper rod was connected with the LRD. 
A

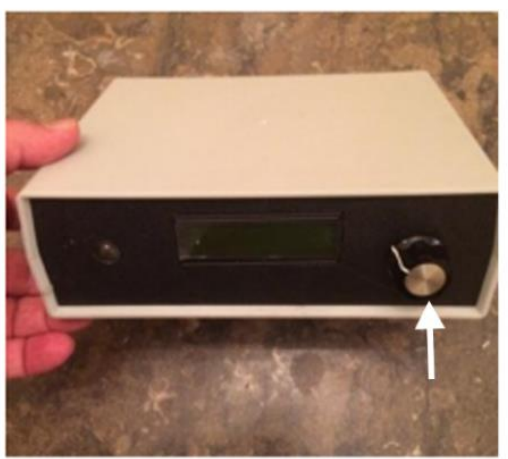

B

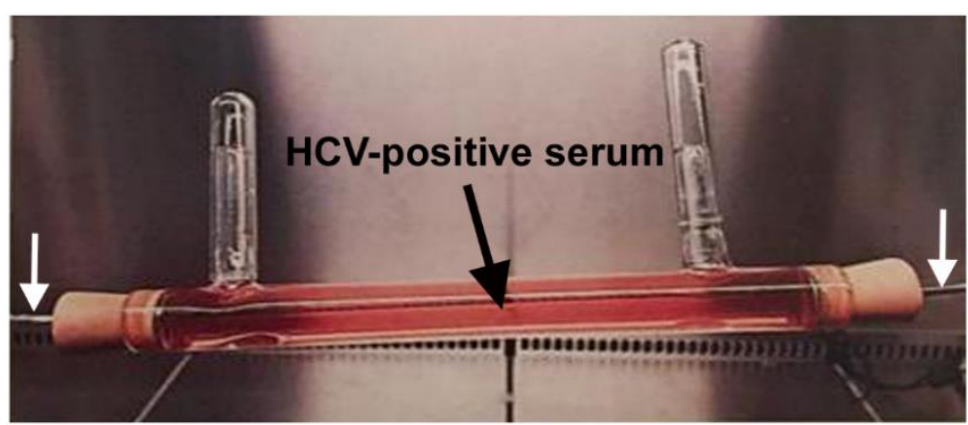

Fig.2. (A), A photomicrograph of primary model of LRD showing the controller (white arrow) for codified amount of ions production. (B), The designated glass tube filled with HCV PCR-positive serum. The glass tube will be connected with the LRD through the input and output electric wires (white arrow)

To evaluate the LRD efficacy against the viral load of HCV PCR-positive serum with different concentrations of the virus were used for this purpose. Hereafter, the low potential electrical frequencies were codified and applied on the serum samples for $30 \mathrm{~min}, 60 \mathrm{~min}$ and $2 \mathrm{hrs}$. The role of the virus concentration and exposure time was used to evaluate the efficacy of the LRD against the HCV PCR-positive serum.

\subsection{Sample collection criteria}

Blood samples collection from HCV PCR-positive patients was conducted in the Pathology Department, Faculty of Medicine, Cairo University, Egypt. This study included 39 Egyptian patients of either sex, diagnosed as HCV PCR-positive. Blood samples used in this study were selected based on several criteria. Sample collection was excluded from pregnant females, children, and those who have chronic diseases such as diabetes, hypertension. The minimum age of inclusion was 20 years old, while HCV PCR-positive serum from patients over 66 years old were excluded from this study. The time of the collected serum samples was during the period from January 2015 to September 2015.

\subsection{Research instrument}

Materials for data collection included a form of informed consent and a demographic survey. The HCV PCR-positive patient's demographic characteristics such as sex, age, marital status and education levels were included in the demographic survey form. Additionally, information about the date of infection, the current treatment protocol was also included in the demographic survey. 


\subsection{Ethical consideration}

This study was performed under the guidelines and ethics approved by the Institutional Ethics Committee of Faculty of Medicine, Cairo University. All of the HCV-infected patients who participated in this study were instructed about the purpose and confidentiality of the study, their right to withdraw from the study at any time without any conditions.

\subsection{Sample collection procedure}

Blood samples were collected from HCV PCR-negative as well as HCV PCR-positive patients in the Pathology Department, Faculty of Medicine, Cairo University. All blood samples were collected in the Biomedical Laboratory under optimal conditions of storage and processing of human blood samples.

\subsection{HCV PCR-negative serum}

Ten samples were taken from volunteers each was divided into two tubes one on ethylenediaminetetraacetic acid (EDTA) and the other on the dry tube for serum collection. Blood sample with EDTA was used for complete blood picture analysis. The blood serum was collected within $1 \mathrm{hr}$ of collection using a centrifuge (15 mins at 2200-2500 RPM).

\subsection{HCV PCR-positive serum}

The LRD device efficacy against HCV was tested by an in vitro study using 39 serum samples. Serum samples were collected from HCV PCR-positive patients coming to the outpatient clinic or inpatient. The serum samples were subjected to LRD for $30 \mathrm{~min}$ or $60 \mathrm{~min}$ or $2 \mathrm{hrs}$. Then the serum samples were tested for viral load by Applied Biosystem Real-time PCR (Thermo Fisher Scientific, Massachusetts, USA). The viral load of HCV PCR-positive serum was investigated before and after treatment with the LRD using the same machine to keep the standard condition of measuring the HCV count.

\subsection{Complete blood profile}

Blood samples of the HCV PCR-negative and HCV PCR-positive were used to investigate the blood parameters, differential counts, after exposure to the LRD device. The blood parameters include hemoglobin, RBCs, platelets, white blood cells (WBCs) and erythrocyte sedimentation rate (ESR). The blood parameters were analyzed before and $2 \mathrm{hrs}$ after exposure to the LRD machine. The blood profile was assayed using a hematology analyzer (Sysmex XS 800i, Sysmex Corporation, Japan) [17].

\subsection{Transmission Electron Microscopy}

Serum samples tested with high viral load were divided into 2 parts for each. The first part was processed and examined by electron microscopy. The other part was subjected to the LRD device for $2 \mathrm{hrs}$ then the sample was processed and examined under the electron microscopy. 


\subsection{Data analysis}

Data were statistically described in terms of mean \pm standard deviation $( \pm S D)$, median and range. Within-group comparison between before and after exposure to LRD, the values were done using Wilcoxon signed-rank test for paired (matched) samples. The $\mathrm{p}$ values less than 0.05 were considered statistically significant. All statistical calculations were done using the computer program SPSS (Statistical Package for the Social Science; SPSS Inc., Chicago, IL, USA).

\section{Results}

\subsection{Scientific theory of LRD}

As shown in Fig.1 and Fig.2, the design of the LRD device depends on the production of the codified special amount of energy from dry batteries as an electric source. The produced energy is simple and safe and will be electronically processed to a low potential codified amount of ions. These electric stimulations or frequencies are coded into the amount of ions that can exterminate the biological contents of HCV such as RNA/DNA or outer envelope.

\subsection{LRD efficacy against $\mathrm{HCV}$}

\subsubsection{High HCV counts and LRD efficacy}

As shown in fig. 3, after 2 hrs of HCV PCR-positive serum exposure to LRD, the viral load in the serum decreased significantly compared with the non-treated HCV PCR-positive serum. The statistical data analysis of the HCV PCR-positive serum after and before exposure to LRD showed a significant decrease $(\mathrm{P}$-value $=0.0001)$ in the viral number of the serum. Compared to the non-treated serum, the mean value of the HCV viral load in the serum decreased by $1 \%$ after treatment with LRD for 2 hrs (Table1). Most of the virus counts (99\%) in the serum samples were exterminated after $2 \mathrm{hrs}$ treatment indicating the efficacy of LRD to reduce the high concentration viral load of the HCV PCR-positive samples at short times.

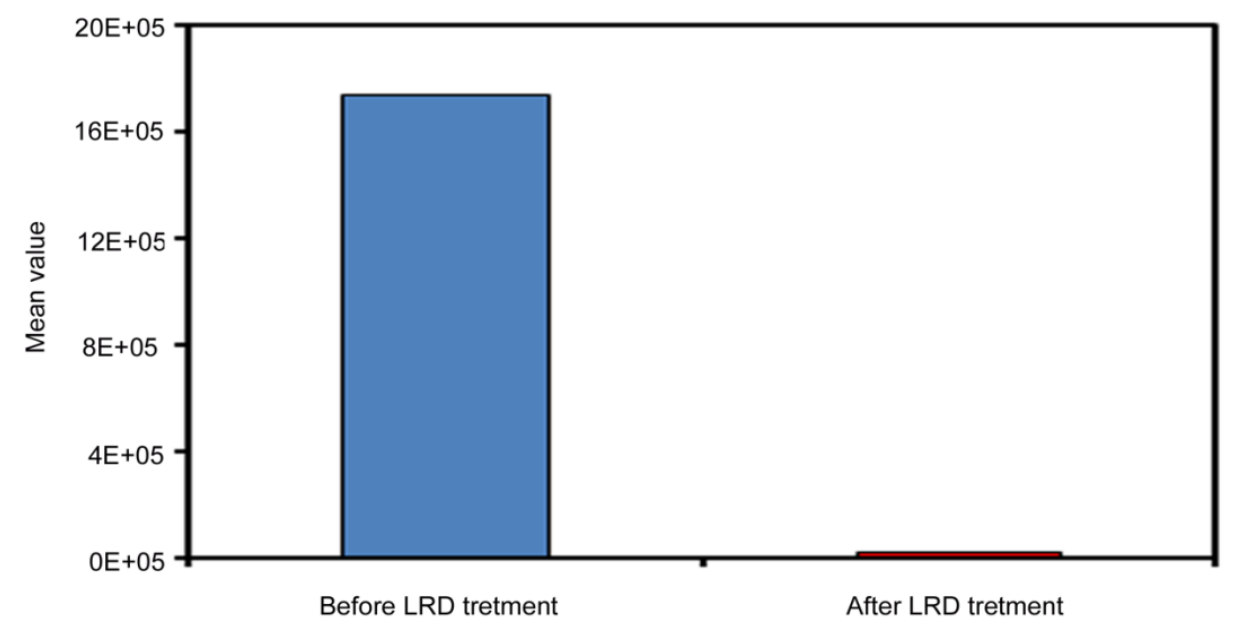

Fig.3. The PCR mean value of HCV in the blood serum of HCV PCR-positive patients pre and $2 \mathrm{hrs}$ after exposure to LRD. The HCV viral load decreased significantly after 2 hrs treatment by LRD 
Asian Journal of Applied Science and Technology (AJAST)

Volume 6, Issue 1, Pages 61-76, January-March 2022

Table 1. The PCR mean value of HCV in blood serum of HCV PCR-positive patients pre and 2 hrs after exposure to LRD. Statistical comparison showed high significant of $p$ value at 0.0001 . Note: The number of the used samples of HCV PCR-positive serum is $39(n=39)$

\begin{tabular}{|c|c|c|}
\hline & $\begin{array}{c}\text { Virus count/ml (pre } \\
\text { exposure) }\end{array}$ & $\begin{array}{c}\text { Virus count/ml (after 2 hrs } \\
\text { exposure) }\end{array}$ \\
\hline Mean & $1,733,439.90$ & $20,906.62$ \\
\hline Number & 39 & 39 \\
\hline SD & $3,410,107.165$ & $77,744.866$ \\
\hline Miniumum & 6,130 & 480,000 \\
\hline Maximum & $19,000,000$ & $1,770.00$ \\
\hline Median & $340,000.00$ & 0 \\
\hline
\end{tabular}

\subsubsection{Low HCV counts and LRD efficacy}

As shown in table 1 and table 3, the highest PCR value of the HCV count in $1 \mathrm{ml}$ each serum sample was 19,000,000 viruses while the lowest value was 6000 viruses. Application of LRD to high HCV count showed and an average of $99 \%$ of the exterminated virus. Additionally, table 2 and fig.4, showed some low HCV counts ranging from 9700 to 68. After exposure to low HCV count into LRD, the exterminated virus was around $86.2 \%$. The reduction of the viral load of low count serum was effective and almost similar to that reduction of the high count serum samples. This data indicated that the efficacy of LRD in the high viral load was almost similar to that low viral load.

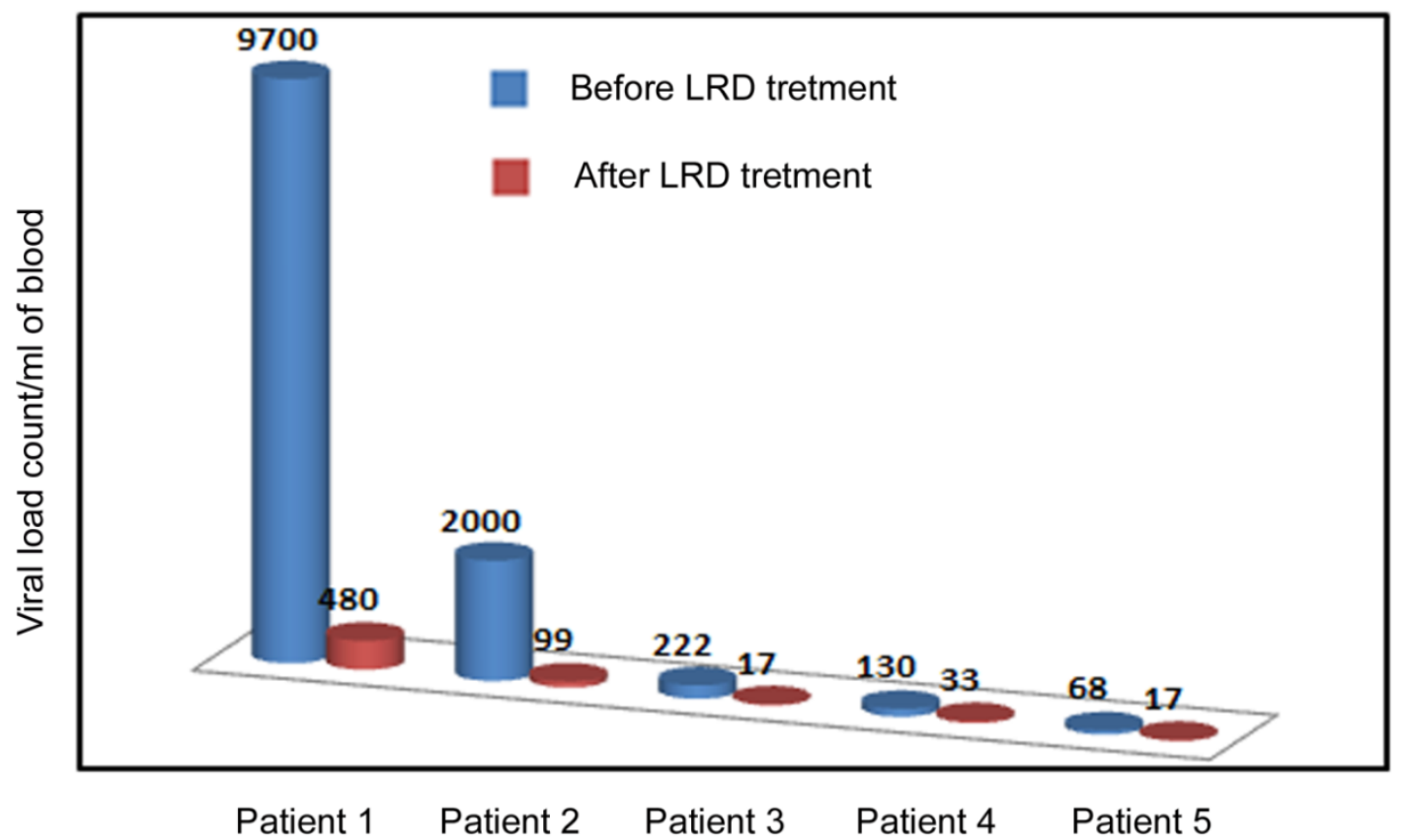

Fig.4. The HCV count in HCV PCR-positive serum of some representative patients with lower PCR values before and $2 \mathrm{hrs}$ after exposure to LRD 
Asian Journal of Applied Science and Technology (AJAST)

Volume 6, Issue 1, Pages 61-76, January-March 2022

Table 2. Some representative samples of HCV PCR-positive serum with low HCV counts before and 2 hrs after exposure to the LRD

\begin{tabular}{|c|c|c|c|c|}
\hline \multirow{2}{*}{ Patients IDs } & \multicolumn{2}{|c|}{ Virus count $/ \mathrm{ml}$} & \multirow{2}{*}{$\begin{array}{c}\text { Exterminated } \\
\text { viruses/ml }\end{array}$} & \multirow{2}{*}{$\begin{array}{l}\text { Exterminated virus/ml } \\
\qquad(\%)\end{array}$} \\
\hline & Before & After & & \\
\hline Patient N\# 01 & 9700 & 480 & 9220 & 95.05 \\
\hline Patient N\# 02 & 2000 & 99 & 1901 & 95.05 \\
\hline Patient N\# 03 & 222 & 17 & 205 & 92.34 \\
\hline Patient N\# 04 & 130 & 33 & 97 & 74.46 \\
\hline Patient N\# 05 & 68 & 17 & 51 & 75 \\
\hline
\end{tabular}

Table 3. Some representative samples of HCV PCR-positive serum with different HCV concentration and the changes in the HCV number before and $2 \mathrm{hrs}$ after exposure to the LRD

\begin{tabular}{|ccccc|}
\hline \multirow{2}{*}{ Patients IDs } & \multicolumn{2}{c}{ Virus count/ml } & Exterminated virus/ml & Exterminated virus/ml \\
\cline { 2 - 4 } & Before & After 2h & & $(\%)$ \\
\hline Sample \#01 Mr. Y.G & 3490000 & 26200 & 3463800 & 99.25 \\
\hline Sample \#02 Miss. F. & 1360000 & 2110 & 1357890 & 99.84 \\
\hline Sample \#03 Miss. M. & 297000 & 1230 & 295770 & 99.59 \\
\hline Sample \#04 Miss. S.F & 181000 & 1780 & 179220 & 99.02 \\
\hline Sample \#05 Mr. R. & 2150000 & 4720 & 2145280 & 99.78 \\
\hline Sample \#06 Mr. K. & 340000 & Negative & 340000 & 100 \\
\hline Sample \#07 Mr. M. H. & 2440000 & Negative & 2440000 & 100 \\
\hline Sample \#08 MissG. H & 73500 & 789 & 72711 & 98.93 \\
\hline Sample \#09 Mr. K.S & 935000 & 1990 & 933010 & 99.79 \\
\hline Sample \#10 Mr. S.H & 1990000 & 587 & 1989413 & 99.97 \\
\hline Sample \#11 Mr. I.G & 1150000 & 1770 & 1148230 & 99.85 \\
\hline Sample \#13 Mr. S.A & 197000 & 806 & 196194 & 99.59 \\
\hline Sample \#14 Mr. S.A. & 3520000 & 177 & 3519823 & 99.99 \\
\hline Sample \#15 Mis E.S. 0 & 117000 & 359 & 1169641 & 97 \\
\hline Sample \#16 Mr. G.A & 2460000 & 4690 & 2455310 & \\
\hline & & & & \\
\hline
\end{tabular}


Asian Journal of Applied Science and Technology (AJAST)

Volume 6, Issue 1, Pages 61-76, January-March 2022

\begin{tabular}{|ccccc|}
\hline Sample \#17 Mis S. M. & 338000 & Negative & 338000 & 100 \\
\hline Sample \#17 Mis S. M. & 338000 & Negative & 338000 & 100 \\
Sample \#19 Miss.R. A. & 551000 & Negative & 551000 & 100 \\
Sample \#20 Mr. A. G. & 331000 & 49200 & 281800 & - \\
Sum of viruses -before & 26427500 & - & - & - \\
\hline $\begin{array}{c}\text { Sum of viruses -after } \\
\% \text { Average of }\end{array}$ & - & 97089 & - & 99.02 \\
\hline
\end{tabular}

\subsection{Exposure time and LRD efficacy}

Table 4 showed the effect of the exposure time on the reduction of the viral load using LRD. With considering to virus concentration in each sample, the average viral load reduction after $\mathrm{HCV}$ PCR-positive serum exposed to LRD for $30 \mathrm{~min}$ was about $95 \%$. While the viral load reduction of the HCV PCR-positive serum was $95 \%$ after 60 min of LRD exposure. The viral load was reduced to86\% after HCV PCR-positive serum was exposed to LRD for $2 \mathrm{hrs.}$

Table 4. Some representative samples of HCV PCR-positive serum and the changes in the HCV count before and after exposure to the LRD at different time points

\begin{tabular}{|c|c|c|c|c|c|c|c|}
\hline \multirow{2}{*}{ Patients IDs } & \multirow{2}{*}{ Sex } & \multirow{2}{*}{$\begin{array}{c}\text { Exposure } \\
\text { time }\end{array}$} & \multirow{2}{*}{ Age } & \multicolumn{2}{|c|}{ Virus count $/ \mathrm{ml}$} & \multirow{2}{*}{$\begin{array}{c}\text { Exterminated } \\
\text { viruses/ml }\end{array}$} & \multirow{2}{*}{$\begin{array}{l}\text { Exterminated } \\
\text { virus } / \mathrm{ml}(\%)\end{array}$} \\
\hline & & & & Before & After & & \\
\hline Patient N\# 01- A. F. & $\mathrm{F}$ & $30 \mathrm{~min}$ & 24 & 130000 & 33400 & 96600 & 74.31 \\
\hline Patient N\# 06 -G. M. & M & $30 \mathrm{~min}$ & 34 & 67900 & 17000 & 50900 & 74.96 \\
\hline Averages & & & & 98950 & 25200 & 73750 & 74.63 \\
\hline Patient N\# 03- E. M. & M & $60 \mathrm{~min}$ & 52 & 95000 & 0 & 95000 & 100 \\
\hline Patient N\# 04- R. Z. & M & $60 \mathrm{~min}$ & 66 & 2000000 & 99100 & 1900900 & 95.045 \\
\hline Averages & & & & 1047500 & 49550 & 997950 & 95.26 \\
\hline Patient N\# 05- A. G. & $\mathrm{F}$ & $120 \min$ & 20 & 1930000 & 260000 & 1670000 & 86.53 \\
\hline Patient N\# 07- N. N. & M & $120 \mathrm{~min}$ & 29 & 9700000 & 480000 & 9220000 & 95.05 \\
\hline Averages & & & & 5815000 & 370000 & 5445000 & 90.79 \\
\hline
\end{tabular}

\subsection{Electron microscopy investigation of treated HCV virus with LRD}

To confirm the efficacy of the LRD against HCV virus, treated and non-treated HCV PCR-positive serum was investigated under electron microscopy. As shown in fig.5, the untreated HCV 


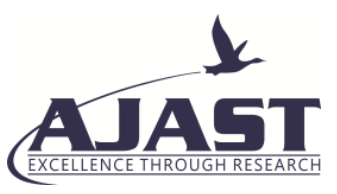

Asian Journal of Applied Science and Technology (AJAST)

Volume 6, Issue 1, Pages 61-76, January-March 2022

PCR-positive serum showed intact and complete whole particles of the HCV virus (Fig.5A). While the treatment of the HCV PCR-positive serum with LRD for 2 hrs destroyed the cell membrane as well as cytoplasmic contents of the virus. The treated serum showed a remnant of degenerated biological materials of the HCV (Fig.5B).
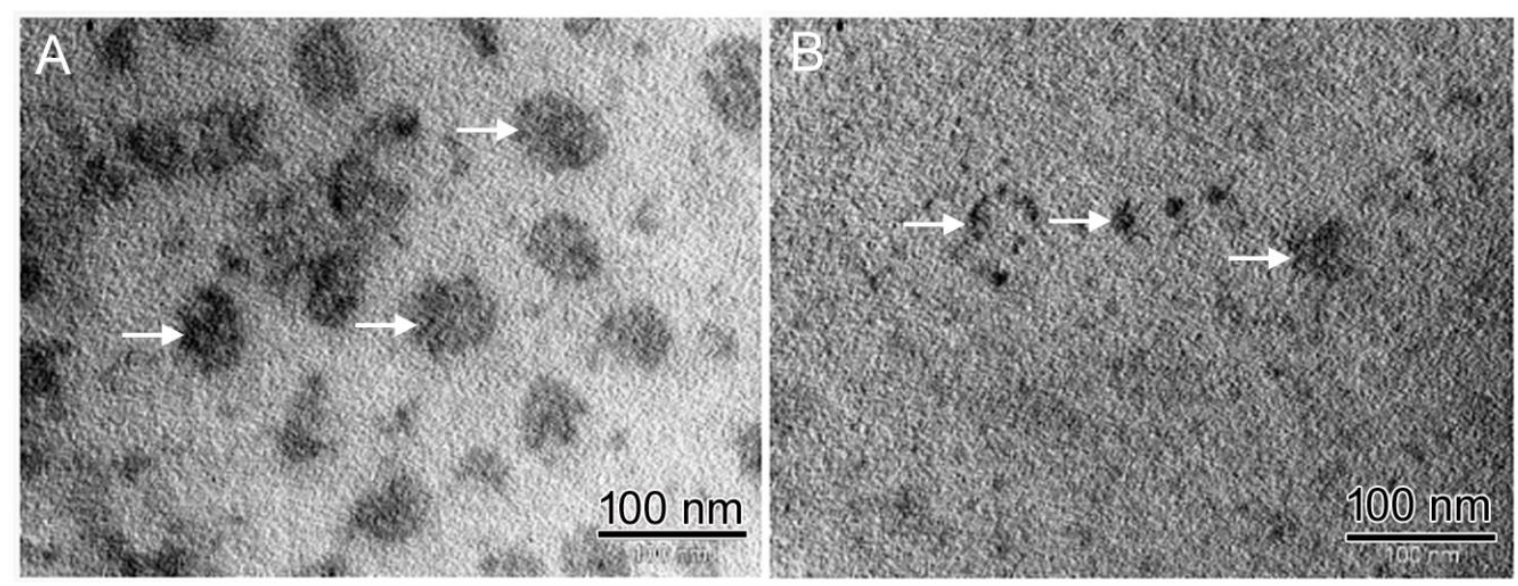

Fig.5. A) Untreated HCV PCR-positive serum under transmission electron microscopy showed particles of HCV without any abnormalities (arrows). (B) After 2 hrs of treated HCV PCR-positive serum with LRD showed a degenerated HCV particles (arrow)

\subsection{LRD safety against blood parameters}

As shown in fig.6 and table 5, the mean value of blood hemoglobin and the number of RBCs, platelets, WBCs and ESR before or after treatment with LRD was the same. The mean p-value of all blood parameters before and after treatment with LRD was higher than the significance value $(\geq$ 0.01). The non-changeable values of the blood parameters before and after exposure to the LRD indicated the efficient treatment of the HCV virus without side effects.

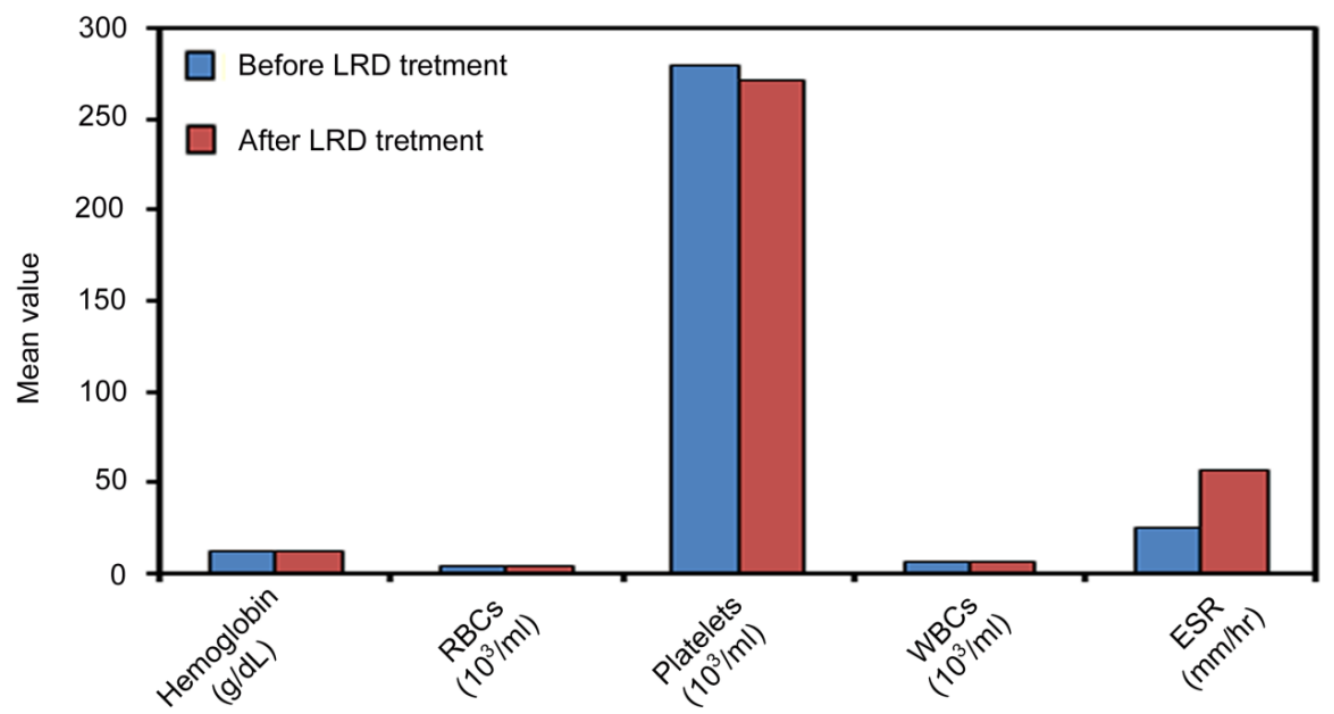

Fig.6. Mean values of some blood parameters of HCV PCR-positive representative patients before and after $2 \mathrm{hrs}$ exposures to LRD. All blood parameters did not show any major changes between before/after treatment with LRD 
Asian Journal of Applied Science and Technology (AJAST)

Volume 6, Issue 1, Pages 61-76, January-March 2022

Table 5. Changes in the blood parameters of HCV PCR-positive representative patients before and after $2 \mathrm{hrs}$ exposures to LRD. There is no significant difference between the pre and 2 hrs after exposure to LRD. Note: significant $P$ value $=0.01$

\begin{tabular}{|c|c|c|c|c|c|c|c|c|c|c|}
\hline & \multicolumn{2}{|c|}{$\begin{array}{l}\text { Hemoglobin } \\
(\mathrm{g} / \mathrm{dL})\end{array}$} & \multicolumn{2}{|c|}{$\begin{array}{c}\text { RBCs } \\
\left(10^{3} / \mathrm{ml}\right)\end{array}$} & \multicolumn{2}{|c|}{$\begin{array}{l}\text { Platelets } \\
\left(10^{3} / \mathrm{ml}\right)\end{array}$} & \multicolumn{2}{|c|}{$\begin{array}{l}\text { WBCs } \\
\left(10^{3} / \mathrm{ml}\right)\end{array}$} & \multicolumn{2}{|c|}{$\operatorname{ESR}(\mathrm{mm} / \mathrm{hr})$} \\
\hline & Pre & Post & Pre & Post & Pre & Post & Pre & Post & Pre & Post \\
\hline Mean & 12.24 & 11.96 & 4.69 & 4.49 & 280.1 & 271.5 & 6.9 & 6.58 & 25.25 & 56.75 \\
\hline No. & 10 & 10 & 10 & 10 & 10 & 10 & 10 & 10 & 4 & 4 \\
\hline SD & 3.04 & 3.11 & 0.92 & 0.92 & 123.99 & 117.83 & 2.37 & 2.33 & 22.52 & 38.02 \\
\hline Minimum & 7.8 & 7.9 & 3.2 & 3.5 & 154 & 156 & 3.4 & 3.5 & 5 & 15 \\
\hline Maximum & 17.2 & 16.9 & 6.2 & 6.2 & 578 & 560 & 11 & 10.9 & 55 & 100 \\
\hline Median & 12.45 & 11.8 & 4.77 & 4.16 & 253 & 242 & 6.65 & 5.9 & 20.5 & 56 \\
\hline $\mathrm{Z}$ & \multicolumn{2}{|c|}{$-0.48(a)$} & \multicolumn{2}{|c|}{$-1.33(\mathrm{a})$} & \multicolumn{2}{|c|}{$-1.58(a)$} & \multicolumn{2}{|c|}{-1.89 (a) } & \multicolumn{2}{|c|}{ - } \\
\hline$P$ value & \multicolumn{2}{|c|}{0.63} & \multicolumn{2}{|c|}{0.19} & \multicolumn{2}{|c|}{0.13} & \multicolumn{2}{|c|}{0.06} & \multicolumn{2}{|c|}{ - } \\
\hline
\end{tabular}

\section{Discussions}

$\mathrm{HCV}$ is the main cause of hepatic chronic disease, with more than 170 million people who tested HCV-PCR-positive worldwide [18,19,20,21]. Furthermore, complications after HCV infection are the main cause of liver transplantation. Complications raised from chronic HCV infection include hepatic decompensation, cirrhosis, and hepatocellular carcinoma [22].

Therefore, treatment strategies to prevent or reduce such complications have been widely investigated, although many obstacles remain without answer. The recent therapies of protection or even treatment of $\mathrm{HCV}$ infection complications using vaccination or antiviral drugs respectively are not completely ideal based on World Health Organization (WHO) standards. Of note, vaccination is not effective to protect from HCV and antiviral drugs produce severe side effects in the infected patients $[9,10,11,12]$. Therefore, it is important to develop standard alternative therapy to reduce $\mathrm{HCV}$ infectivity or antiviral drug complications with low cost and painless treatment.

Outside the host, viruses will eventually lose their ability to infect cells due to conformational changes that occur to proteins on the viral capsid. In order to undergo a conformational change, these proteins require energy to activate the chemical reaction that leads to the conformational change. Several viruses (respiratory syncytial virus, poliovirus, and norovirus) have nonlinear Arrhenius plots, suggesting that there is more than a single pathway for inactivation of these viruses. 
Viral inactivation occurs when the proteins on the surface of the particle change shape, and as a result, lose their ability to functionproperly, removing their ability to infect cells.

The designated novel LRD system in the current study depends mainly on the production of the low potential of codified amount of ions that can reduce HCV viral load and destroy the cytoplasmic contents of HCV virus. Of note, some recent studies support the data raised from this study. Interestingly, the codified amount of ions stimulation of the auricular vagus nerve reduced the complications of lung inflammation caused by the COVID-19 virus [23]. Furthermore, patients infected with human immunodeficiency virus type 1 exposed to low electric potential frequencies showed lower side effects and reduced viral infectivity [24,25]. Treatment of HCV using the codified amount of ions or ultrasound energy wasn't investigated previously. However, the HCV infection complications such as hepatic carcinoma was treated with high-intensity focused ultrasound energy [26]. Moreover, viral exposure to ultraviolet light irradiation (wavelength = $253.7 \mathrm{~nm}$ ) with an intensity of $450 \mathrm{micro} \mathrm{W} / \mathrm{cm} 2$ for $2 \mathrm{~min}$ and the viral exposure to 56 degrees $\mathrm{C}$ for 40 min efficiently inactivated HCV [27].

In the current study, HCV PCR-positive serum treatment with LRD showed a significant reduction in both higher and lower concentrations of serum HCV. Additionally, more than $99 \%$ of the viral load was reduced after $2 \mathrm{hrs}$ of HCV PCR-positive serum treatment with LRD. Additionally, the LRD treatment of infected patient blood with HCV didn't affect the blood cells or serum contents. Further studies on experimental animals will be conducted soon to investigate the safety of this new method. The mechanism of how the produced codified amount of ions destroys the serum HCV rather than other blood components needs more investigations. It is expected that the specificity of the fragile viral envelope to the produced codified amount of ions by LRD is higher than that of blood cells. This hypothesis is proved with previously published studies concerning the effect of ions stimulations on the cell membrane fluidity compared with that of the viral envelope. In his study, the codified amount of ions reduced the cell membrane fluidity, in turn affecting human immunodeficiency virus type 1 infectivity [28,29]. Obviously, it was hypothesized that the lower potential sensitivity of immunodeficiency virus type 1 would be higher than blood cells. The difference in the sensitivity may be due to the lower fluidity of the viral envelope compared with that of the plasma cell membrane [29]. Moreover, it is well known that plasma membrane fluidity and phospholipid bilayer density may affect cell functions [30,31]. From another hand, there was a difference between the thickness, function and structure of the viral envelope and eukaryotic cell plasma membrane (blood cells in this study). It is known that the viral envelope thick ness measured about $6.34 \pm 0.49 \mathrm{~nm}$ and was composed of a lipid bilayer [30]. While the plasma membrane thickness of the blood cells measured about $5 \mathrm{~nm}$ to $10 \mathrm{~nm}$ and was composed of phospholipid bilayer, glycoproteins and glycolipids [32]. A recent study performed by Gravemann et al.2018, reported that due to the sensitivity of the lipid envelop of the hepatitis A virus against the ultraviolet light, its viral infectivity was reduced when it was exposed to the ultraviolet light in 


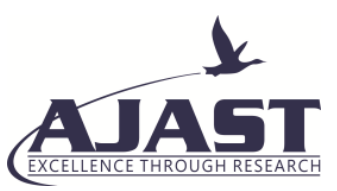

Asian Journal of Applied Science and Technology (AJAST)

Volume 6, Issue 1, Pages 61-76, January-March 2022

vitro [33]. Previously it was reported that the molecular structure of HCV such as lipoproteins and glycoproteins have been correlated with altered antiviral drugs efficacy [34,35]. This information confirms the effectiveness of the codified ions produced by LRD on the molecular structure of the HCV. Therefore, we concluded that the codified amount of ions produced by LRD can specifically destroy the HCV viral envelope and deeper into the nucleic acid materials rather than blood cells and blood components. This data confirms that a novel LRD system considers as an alternative therapy with lower side effects and is safe for normal cells.

\section{Conclusion}

HCV treatment or protection using an alternative therapy with lower side effects is a big challenge. Recently, non-invasive and alternative therapy is the most suitable strategy for HCV treatment. The obtained results from this study showed a higher reduction of HCV viral load (99\%) in the PCR-positive serum after treatment with LRD. Additionally, the treatment with LRD didn't produce any changes in the blood components such as red blood cells, white blood cells and hemoglobin. The viral load reduction using LRD may be due to the destruction of the cytoplasmic materials of the HCV by the produced codified amount of ions. The difference in the function and structure of the viral envelope and plasma membrane might explain the specificity of LRD to exterminate HCV virus in the blood rather than blood cells. The data obtained from this study is important to design a new strategy for an alternative therapy for HCV treatment with low coat and side effects.

\section{List of abbreviations}

HCV: Hepatitis C virus; LRD: Life Restoration Device; EDTA: Ethylenediaminetetraacetic acid; PCR: Polymerase chain reaction; ESR: Erythrocyte sedimentation rate; WBCs: White blood cells

\section{Declarations}

\section{Source of Funding}

This research did not receive any grant from funding agencies in the public, commercial, or not-for-profit sectors.

\section{Consent for publication}

Authors declare that they consented for the publication of this research work.

\section{Availability of data and materials}

Data are available from the corresponding author on reasonable request.

\section{Competing Interests Statement}

The authors declare no competing financial, professional and personal interests.

\section{Ethical Approval and Consent to participate}

All experiments are performed under the ethical guidelines for the use of human samples and approved by the ethical guidelines committee in Cairo University, Cairo, Egypt. 
Asian Journal of Applied Science and Technology (AJAST)

Volume 6, Issue 1, Pages 61-76, January-March 2022

\section{Authors' contributions}

WEM conceived of the present idea, MGS developed the idea and collected the data study, SS verified the analytical methods, MASBG contributed to analysis and wrote the manuscript, MSNM and AMA contributed to analysis and wrote the manuscript. Also, all authors reviewed the results and approved the final version of the manuscript.

\section{References}

1. Lavanchy D. (2008). Chronic viral hepatitis as a public health issue in the world. Best practice \& research. Clinical gastroenterology, 22(6), 991-1008. https://doi.org/10.1016/j.bpg.2008.11.002.

2. Sherman, I. L., \& Eichenwald, H. F. (1956). Viral hepatitis: descriptive epidemiology based on morbidity and mortality statistics. Annals of internal medicine, 44(6), 1049-1069. https://doi.org/10.7326/0003-4819-44-6-1049.

3. Trepo C. (2014). A brief history of hepatitis milestones. Liver international : official journal of the International Association for the Study of the Liver, 34 Suppl 1, 29-37. https://doi.org/10.1111/liv.12409.

4. Razavi H. (2020). Global Epidemiology of Viral Hepatitis. Gastroenterology clinics of North America, 49(2), 179-189. https://doi.org/10.1016/j.gtc.2020.01.001.

5. Kim, H. S., \& El-Serag, H. B. (2019). The Epidemiology of Hepatocellular Carcinoma in the USA. Current gastroenterology reports, 21(4), 17. https://doi.org/10.1007/s11894-019-0681-X.

6. Levrero, M., \& Zucman-Rossi, J. (2016). Mechanisms of HBV-induced hepatocellular carcinoma. Journal of hepatology, 64(1 Suppl), S84-S101. https://doi.org/10.1016/j.jhep.2016.02.021.

7. Monaco, S., Mariotto, S., Ferrari, S., Calabrese, M., Zanusso, G., Gajofatto, A., Sansonno, D., \& Dammacco, F. (2015). Hepatitis C virus-associated neurocognitive and neuropsychiatric disorders: Advances in 2015. World journal of gastroenterology, 21(42), 11974-11983. https://doi.org/10.3748/wjg.v21.i42.11974.

8. González-Grande, R., Jiménez-Pérez, M., González Arjona, C., \& Mostazo Torres, J. (2016). New approaches in the treatment of hepatitis C. World journal of gastroenterology, 22(4), 1421-1432. https://doi.org/10.3748/wjg. v22.i4.1421.

9. Teodor, D., Teodor, A., Grigore, L., Jugănariu, G., Dorobăţ, C. M., Miftode, E., \& Azoicăi, D. (2012). Side effects of antiviral therapy in hepatitis C virus infection-sarcoidosis - case report. Revista medico-chirurgicala a Societatii de Medici si Naturalisti din Iasi, 116(4), 1039-1043.

10. Mayberry, J., \& Lee, W. M. (2019). The Revolution in Treatment of Hepatitis C. The Medical clinics of North America, 103(1), 43-55. https://doi.org/10.1016/j.mena.2018.08.007.

11. Bailey, J. R., Barnes, E., \& Cox, A. L. (2019). Approaches, Progress, and Challenges to Hepatitis C Vaccine Development. Gastroenterology, 156(2), 418-430. https://doi.org/10.1053/j.gastro.2018.08.060.

12. Cox A. L. (2020). Challenges and Promise of a Hepatitis C Virus Vaccine. Cold Spring Harbor perspectives in medicine, 10(2), a036947. https://doi.org/10.1101/cshperspect.a036947. 
Asian Journal of Applied Science and Technology (AJAST)

Volume 6, Issue 1, Pages 61-76, January-March 2022

13. Bean P. (2002). The use of alternative medicine in the treatment of hepatitis C. American clinical laboratory, 21(4), 19-21.

14. Yang, Z., Zhuang, L., Lu, Y., Xu, Q., \& Chen, X. (2014). Effects and tolerance of silymarin (milk thistle) in chronic hepatitis $\mathrm{C}$ virus infection patients: a meta-analysis of randomized controlled trials. BioMed research international, 2014, 941085. https://doi.org/10.1155/2014/941085.

15. Hart, H., Reid, K., \& Hart, W. (1993). Inactivation of viruses during ultraviolet light treatment of human intravenous immunoglobulin and albumin. Vox sanguinis, 64(2), 82-88. https://doi.org/10.1111/j.1423-0410.1993. tb02523.x.

16. Roberts, P., \& Hope, A. (2003). Virus inactivation by high intensity broad spectrum pulsed light. Journal of virological methods, 110(1), 61-65. https://doi.org/10.1016/s0166-0934(03)00098-3.

17. Takubo, T., Tatsumi, N., Satoh, N., Matsuno, K., Fujimoto, K., Soga, M., Yamagami, Y., Akiba, S., Sudoh, T., \& Miyazaki, M. (2002). Evaluation of hematological values obtained with reference automated hematology analyzers of six manufacturers. The Southeast Asian journal of tropical medicine and public health, 33 Suppl 2, $62-67$.

18. Rabaan, A. A., Al-Ahmed, S. H., Bazzi, A. M., Alfouzan, W. A., Alsuliman, S. A., Aldrazi, F. A., \& Haque, S. (2020). Overview of hepatitis C infection, molecular biology, and new treatment. Journal of infection and public health, 13(5), 773-783. https://doi.org/10.1016/j.jiph.2019.11.015.

19. Adinolfi, L. E., Nevola, R., Lus, G., Restivo, L., Guerrera, B., Romano, C., Zampino, R., Rinaldi, L., Sellitto, A., Giordano, M., \& Marrone, A. (2015). Chronic hepatitis C virus infection and neurological and psychiatric disorders: an overview. World journal of gastroenterology, 21(8), 2269-2280.

20. Tanwar, S., Rhodes, F., Srivastava, A., Trembling, P. M., \& Rosenberg, W. M. (2020). Inflammation and fibrosis in chronic liver diseases including non-alcoholic fatty liver disease and hepatitis C. World journal of gastroenterology, 26(2), 109-133. https://doi.org/10.3748/wjg.v26.i2.109.

21. Kim, A. I., \& Saab, S. (2005). Treatment of hepatitis C. The American journal of medicine, 118(8), 808-815. https://doi.org/10.1016/j.amjmed.2005.01.073.

22. Younossi Z. M. (2017). Hepatitis C Infection: A Systemic Disease. Clinics in liver disease, 21(3), 449-453. https://doi.org/10.1016/j.cld.2017.03.001.

23. Kaniusas, E., Szeles, J. C., Kampusch, S., Alfageme-Lopez, N., Yucuma-Conde, D., Li, X., Mayol, J., Neumayer, C., Papa, M., \& Panetsos, F. (2020). Non-invasive Auricular Vagus Nerve Stimulation as a Potential Treatment for Covid19-Originated Acute Respiratory Distress Syndrome. Frontiers in physiology, 11, 890. https://doi.org/10.3389/fphys.2020.00890.

24. Kumagai, E., Tominaga, M., \& Harada, S. (2004). Sensitivity of chronically HIV-1 infected HeLa cells to electrical stimulation. Applied microbiology and biotechnology, 63(6), 754-758. https://doi.org/10.1007/s00253003-1410-8. 
25. Kumagai, E., Tominaga, M., \& Harada, S. (2011). Sensitivity to electrical stimulation of human immunodeficiency virus type 1 and MAGIC-5 cells. AMB Express, 1(1), 23. https://doi.org/10.1186/21910855-1-23.

26. Mearini L. (2013). High intensity focused ultrasound, liver disease and bridging therapy. World journal of gastroenterology, 19(43), 7494-7499. https://doi.org/10.3748/wjg.v19.i43.7494.

27. Song, H., Li, J., Shi, S., Yan, L., Zhuang, H., \& Li, K. (2010). Thermal stability and inactivation of hepatitis C virus grown in cell culture. Virology journal, 7, 40. https://doi.org/10.1186/1743-422X-7-40.

28. Kojima, J., Shinohara, H., Ikariyama, Y., Aizawa, M., Nagaike, K., \& Morioka, S. (1991). Electrically controlled proliferation of human carcinoma cells cultured on the surface of an electrode. Journal of biotechnology, 18(1-2), 129-139. https://doi.org/10.1016/0168-1656(91)90241-m.

29. Harada, S., Yusa, K., Monde, K., Akaike, T., \& Maeda, Y. (2005). Influence of membrane fluidity on human immunodeficiency virus type 1 entry. Biochemical and biophysical research communications, 329(2), 480-486. https://doi.org/10.1016/j.bbrc.2005.02.007.

30. Hawes, P. C., Netherton, C. L., Wileman, T. E., \& Monaghan, P. (2008). The envelope of intracellular African swine fever virus is composed of a single lipid bilayer. Journal of virology, 82(16), 7905-7912. https://doi.org/ 10.1128/JVI.00194-08.

31. Nicolson G. L. (2013). Update of the 1972 Singer-Nicolson Fluid-Mosaic Model of Membrane Structure. Discoveries (Craiova, Romania), 1(1), e3. https://doi.org/10.15190/d.2013.3.

32. Delaunay J. (1977). The enzymes of the red blood cell plasma membrane. Biomedicine/[publiee pour l'A.A.I. C.I.G.], 26(6), 357-361.

33. Gravemann, U., Handke, W., Lambrecht, B., Schmidt, J. P., Müller, T. H., \& Seltsam, A. (2018). Ultraviolet C light efficiently inactivates nonenveloped hepatitis $A$ virus and feline calicivirus in platelet concentrates. Transfusion, 58(11), 2669-2674. https://doi.org/10.1111/trf.14957.

34. Vercauteren, K., Mesalam, A. A., Leroux-Roels, G., \& Meuleman, P. (2014). Impact of lipids and lipoproteins on hepatitis C virus infection and virus neutralization. World journal of gastroenterology, 20(43), 15975-15991. https://doi.org/10.3748/wjg.v20.i43.15975.

35. Yost, S. A., Wang, Y., \& Marcotrigiano, J. (2018). Hepatitis C Virus Envelope Glycoproteins: A Balancing Act of Order and Disorder. Frontiers in immunology, 9, 1917. https://doi.org/10.3389/fimmu.2018.01917. 